\title{
HASIL PENELITIAN \\ KEHIDUPAN SOSIAL DAN KEAGAMAAN NELAYAN PULAU
}

\section{OLEH : AHMAD RAHMAN}

I

Masyarakat nelayan seringkali digolongkan sebagai masyarakat serba kekurangan, penghasilan rendah, pendapatan tidak menentu, dan pendidikan kurang. Mereka bermukim di sepanjang pantai, di atas rumahrumah sederhana dimana sarana dan lingkungannya kurang memadai. Motorisasi perahu sebagai unsur modern telah merubah tradisi layar, pada mulanya membangkitkan kegairahan dan menambah produksi, namun hanya dapat memberi keuntungan para ponggawa, sedangkan sawi nelayan biasa, tetap mereka hidup dengan keterbatasan, terjerat dengan utang. Sekalipun mereka tidak terlepas dari sasaran pembangunan pedesaan, namun mereka belum banyak menikmati hasil pembangunan seperti warga pedesaan lainnya.

Kajian masyarakat pulau sudah sering dilakukan. Di Pulau Sembilan dimana salah satu pulaunya dijadikan lokasi penelitian, sekurang-kurangnya dua peneliti dari PLPIIS Unhas telah melakukan penelitian. Demianus Resusun telah mengadakan penelitian pada tahun 1978, dan ia menitik beratkan tentang aspek-aspek sosial ekonomi, dan lahir sebuah ungkapan kemudian dijadikan judul penelitiannya "narekko de' namahasa wise'e temmakke lisei uringnge" (kalau dayung tidak basah, periuk tidak akan berisi). Pada tahun 1982, Rusdin Pohan meneliti tentang pola kebutuhan pokok keluarga Nelayan.

Dari kedua tulisan di atas dan beberapa tulisan yang berhubungan masyarakat nelayan, telah memberi gambran tentang kehidupan mereka. Untuk menggambarkan mutu kehidupan masyarakat nelayan, diperlukan pengelahuan terhadap taraf hidupnnya, oleh karena itu mutu kehidupan lebih banyak menyangkut isi dan makna kehidupan itu sendiri, maka banyak aspek yang dapat mempengaruhi kehidupan mereka termasuk aspek agama. Aspek agama yang turut mempengaruhi kehidupan nelayan dirasa masih kurang mendapat perhatian selama ini, maka tulisan ini selain mengemukakan kehidupan sosial kaum nelayan pulau, juga akan memberi deskripsi tentang kehidupan keagamaan mereka.

Dalam pengumpulan data, dipergunakan teknik wawancara dan observasi. Sebelum sampai di lokasi penelitian, terlebih dahulu mencari informasi kunci di beberapa instansi di Sinjai. Para informan di lokasi terdiri atas Kepala Kelurahan dan aparatnya. Imam Kelurahan/Imam Lingkungan, guru sekolah, guru mengaji, manteri/suster, dukun, tokoh masyarakat, tokoh agama, baik dari Muhammadiyah maupun dari "Ahlusunnah" dari duaetnis yaitu Bugis dan Bajo.

\section{II}

Pulau Kambuno adalah ibukota Kelurahan Pulau sembilan Kecamatan Sinjai Utara. Untuk sampai di pulau tersebut, kita dapat naik kapal motor dari Desa Lappa (tempat pelelangan ikan) dengan ongkos Rp. 500,-. Perjalanan 13 mil dapat ditempuh sekitar 3

No. 1 \& 2 Thn. I Juli / Desember 1990 
jam, luas wilayahnya $0,75 \mathrm{~km}$ dan $2 / 3$ adalah lokasi pemukiman, dan selebihnya adalah bukit berbatu yang ditumbuhi tanaman seperti kelapa, mangga, asam, sukun dan scbagainya. Nampaknya luas pulau Kambuno scmakin bcrtambah karcna sempitnya pemukiman menyebabkan penduduk membuat pemukiman sepanjang pantai dengan onggokan batu karang.

Penduduk pulau Kambuno (1989) berjumlah 1902 jiwa, terdiri atas laki-laki 966 jiwa dan perempuan 936. Demikian jumlah penduduk laki-laki dan perempuan agak seimbang, walaupun jumlah laki-laki lebih dari limapuluh persen, sedangkan jumlah wanita kurang lima puluh persen. Jumlah kepala keluarga 304, jadi kalau dirata-ratakan setiap rumah tangga dihuni oleh 6,2 jiwa. Mereka mendiami rumah panggung berdempetan mengikuti jalan/lorong yang telah ditata sejak tahun 1962. Sebahagian penduduk (24 KK) mendiami rumah permanen/scmi permanen, dan masih ada juga dua tiga rumah yang sebagian atapnya adalah genten dari Tegal (Jawa) yang menandakan bahwa pemiliknya dahulu adalah passompe.

Sekilar tahun 1937 didirikan sikola Ara' cabang dari Madasah Wathaniyah yang didirikan oleh Puang Kali Muhammad Taherong di Balannipa (Sinjai) dan tidak lama kemudian (1938) didirikan juga sckolah Muhammadiyah namun kedua sckolah dialas hanya bertahan sampai tiga tahun setelah bcrhasil menamatkan muridnya. Tamatan kedua sekolah diatas sebahagian melanjutkan ke Balannipa-. Pada tahun 1969, didirikan PGA Muhammadiyah disamping mesjid, namun sckolah ini hanya sampai satu tahun. Sekolah Mcncngah Ekonomi (SMEP) beberapa kali menamatkan muridnya kemudian ditutup pad tahun 1975 karcna kekurangan murid, dan dua tahun terakhir ini didirikan lagi SMP, tapi tidak bisa dilanjutkan dengan alasan yan sama yaitu kekurangan murid. Sarana pendidikan sekarang hanya 2 buah SD dan 1 TK. Menurut salah seorang Kepala Sekolah SD, bahwa kesadaran masyarakat memasukkan anaknya di sekolah sudah cukup tinggi namun sebahagian anak laki-laki setelah naik kelas tiga tidak dapat mengikuti pelajaran dengan baik karena membantu orang tuanya melaut bahkan ada diantaranya putus sekolah.

Untuk melayani kesehatan masyarakat, telah ditempatkan satu orang mantcri, dan satu orang suster (sekarang suami dan istcri). Mereka tinggal di Puskemas pembantu di Pulau Kambuno. Menurut Pak Manteri, bahwa kesadaran warga masyarakat untuk berobat di Puskesmas sudah ada, namun masyarakat sckitar pulau ini kebanyakan berobat di Sinjai, karena disamping fasilitas puskemas kurang memadai, transportasi umum antar pulau juga tidak ada.

\section{III}

Suku Bajo adalah penghuni pertama pulau sembilan termasuk pulau Kambuno, mereka hidup diatas perahu. Seorang informan menceritakan bahwa pada tahun 1930-an, baru 17 buah rumah, dan ketika dibuka Madrasah Wathaniyah dan sekolah Muhammadiyah belum ada orang Bajo masuk sekolah. Pemerinlah menganjurkan supaya orang Bajo membuat pcrumahan di darat, maka secara bcrangsur-angsur mereka tinggalkan perahunya, dan sekaran mereka menetap di darat. Beberapa informan dari etnis Bajo menceritakan bahwa suku Bajo berasal dari Gowa, ketika ditebang pohon Walenreng, terjadi banjir sehingga anak perempuan Bajo hanyut dan tcrsangkut di daerah Gowa. Kemudian raja Gowa menjadikan isteri dari 
perkawinan itu melahirkan anak yang kemudian menjadi raja turun temurun di kerajaan Gowa.

Suku Bajo menempati bahagian selatan Pulau Kambuno pemukimannya dinamai kampong Bajo. Mereka telah kawin mawin dengan orang Bugis, begitu membaurnya sehingga sulit lagi untuk membedakan dengan orang Bugis. Nampaknya orang Bajo yang berdarah Bugis tidak mau lagi menonjolkan etnisnya, bahkan anak-anak mereka yang berumur 25 tahun ke bawah tidak tahu lagi berbahasa Bajo. Tradisi orang Bajo yang masih ada sekarang ialah menaikkan ula-ula menjelang pesta perkawinan. Ula-ula bendera terbuat dari kain, warnanya biasa merah tua dan berbentuk manusia.

Tidak diketahui dengan pasti siapa orang Bugis pertama mendiami pulau ini, namun diperoleh informasi bahwa sebahagian besar mereka berasal dari pesisir pantai Teluk Bone, seperti Kajuara, Pattiro, Borengnge dan sebahagian dari Sinjai. Perpindahan orang Bugis ke Pulau Kambuno terutama pada masa DI/TII (1951-1965).

Pelapisan sosial baik pada suku Bugis maupun Bajo sekarang ini sulit diidentifikasi secara jelas. Sistim pelapisan sosial orang Bugis yaitu anakarun, todeceng dan ata beserta semua simbol-simbolnya telah lamapudar. Begitu pula orang Bajo terdapat lapisan sosial yang dikenal lolo ponggawa, galarang dan ata tinggal menjadi cerita orang tua-tua. Memang masih ada orang Bugis dipanggil petta dan anaknya andi begitu pula masih ada dikenal sebagai lolo (bangsawan). Bajo, namun mereka diperlakukan sama dengan orang kebanyakan. Elit sosial muncul atas dasar prestasi tingkat pendidikan, tingkat kemampuan ekonomi. Dalam kehidupan masyarakat nelayan di Pulau Kambuno orang yang memiliki modal yang dapat membantu pekerjaannya disebut ponggaha mereka itu diperlakukan strata ini.

Dilihat dari persepsi keagamaan di pulau Kambuno, dapat dibagi atas Muhamadiyah dan "Ahlusunnah". Muhammadiyah masuk pulau ini pada tahun 1930 dibawah oleh Muhammad Syurakati Sayid seorang muballig dari Balannipa Sinjai, yang pertama kali menerima organisasi ini di Pulau Kambuno ialah Abd. Kadir Usman, kemudian ia diangkat menjadi ketua. Pelaksanaan ibadah menurut paham Muhammadiyah semakin nampak pada masa DI/TII (1952-1965). Terdapat persamaan pemahaman syariat dan pelaksanaan ibadat antara organisasi Muhammadiyah dengan gerakan DI/TII. Beberapa orang Kambuno ikut mendukung gerakan DI/TII, kemudian kembali menjadi tokoh masyarakat dan tokoh agama melanjutkan tradisi keagamaan ketika mereka berada di "hutan".

Golongan "Ahlusunnah" tidak nampak dipermukaan terutama setelah Muhammadiyah ada di daerah ini. Abd. Kadir Usman sebagai ketua, kemudian diangkat menjadi Imam kampung mempunyai kewenangan untuk menentukan corak pelaksanaan ibadah di mesjid yang satu-satunya itu. Begitu pula "Ahlusunnah" tidak mempunyai tokoh yang dapat dijadikan sebagai "pembela" atas paham yang mereka anut. A. M. umpamanya seorang Bajo yang sering tampil membaca khuthbah, belum berani mengadakan keritikan atas paham dan pelaksanaan ibadat, sekalipun ia berbeda pendapat. Kenyataan sekarang, golongan "Ahlusunnah" tidak banyak memegang peranan, baik dibidang ekonomi maupun dibidang keagamaan. Kalau kita bertanya, golongan mana yang terbanyak di pulau ini, akan diperoleh jawaban bervariasi, ada yang mengatakan $75 \%$ Muhammadiyah, ada juga mengatakan $90 \%$, bahkan ada yang mengatakan $100 \%$.

No. 1 \& 2 Thn. I Juli / Desember 1990 
Tetapi setelah ditelusuri, diperoleh gambaran sekurang-kurangnya 50\% warga masyarakat adalah pendukung "Ahlusunnah".

Pada tahun 1980, K. H. Marzuki Hasan pendiri Pesantren Darul Istiqamah Maccope (Maros) membuka juga cabang di Sinjai, kemudian ia mengadakan pengajian pada mesjid yang dibangun oleh simpatisannya di dekat pasar Senteral Sinjai, dan mesjid itu dinamai Nurut Tijarah. Beberapa tokoh masyarakat Pulau Kambuno dari Muhammadiyah termasuk Imam Lingkungan, sering mengikuti pengajian itu. Mereka ini membawa pemahaman baru yang dianggap lebih "keras" dari paham Muhammadiyah, dan golongan ini dinamai oleh warga masyarakat golongan pesanteren, yang conderung merubah tradisi yang sudah berlaku karena dianggap bid'ah dan bertentangan dengan hadits Nabi.

\section{IV}

Setelah Islam diterima menjadi agama kerajaan, kemudian dianut oleh masyarakat umum (abad ke-17), maka sara'(syariat) menjadi bagian panngaddereng yaitu wujud kebudayaan Bugis yang mengandung normanorma yang dinyatakan dalam ade (adat), rapang (ibarat), wari (norma), bicara (undangundang) kemudian sara (syariat). Panngaddereng merupakan wujud ideal dari kebudayaan Bugis Makassar yang mengatur tata kelakuan dan mengekspresikan kebudayaannya dalam segala aspek kehidupan masyarakat. Seorang Bugis takut dinamai kapere (kafir) karena orang kapere itu adalah keluar dari panngaddereng berarti hilang sirinya (harga dirinya).

Menurut orang Kambuno, seseorang yang dianggap baik, kalau ia pagama yaitu patuh melaksanakan perintah agama, dan indika- sinya rajin melaksanakan shalat lima waktu terutama di mesjid, dan sering juga diberi predikat orang seperti itu masale (arti harfiahnya orang shaleh atau orang baik). Seorang pemuda dari luar pulau ingin melamar anak gadis di pulau Kambuno, dari keluarga gadis itu sering mempertanyakan apakah ia tahu mengaji atau apakah ia passempajang (rajin shalat).

Di Pulau Kambuno hanya satu mesjid sebagai tempat ibadah ketika diadakan penelitian ini sementara dibangun langkara di kampong Boko. Waktu shalat dapat diketahui dengan bunyi beduk sebanyak rakaat shalat. Ketika ada pengeras suara, beduk tetap dipergunakan sampai tahun 1968, setelah seorang muballig yang bernama Uztas Usman bekas anggota DI/TII memberikan fatwah bahwa beduk itu adalah bid'ah dan hams disingkirkan dari mesjid. Akibatnya tcrjadi dua kelompok, ada yang pro dan ada yang kontra, sehingga ketika beduk dikeluarkan dari mesjid, pada malam harinya ada juga yang memasukkannya. Fatwah ini semakin kuat ketika Pak Camat waktu itu mendukungnya dan sampai sekarang beduk tidak pernah lagi kedengaran.

Untuk menertibkan waktu shalat di mesjid, telah dibuat jadwal waktu yang ditulis di atas papan. Jadwal itu memuat waktu adzan dan kamat, sehingga seorang yang datang di mesjid ia terlebih dahulu melihat jadwal itu, kalau jam menunjukkan waktu kamat, maka ia tidak shalat tahiyatul mesjid, tetapi ia berdiri menunggu orang kamat. Setiap waktu ada orang yang datang ke mesjid, dan waktu yang paling banyak jemaahnya adalah waktu shalat Magrib biasa sampai 70 orang terdiri atas lakilaki dan perempuan, sedangkan waktu subuh yang paling kurang, yaitu antara 10 sampai 20 orang, bahkan biasa hanya 5 orang. Waktu dhuhur juga kurang jemaah terutama laki-laki 
karena berada di laut, tetapi biasa juga ramai kalau murid-murid sekolah praktek shalat, sedangkan waktu-waktu lain jemaah mesjid antara 10 sampai 30 orang.

Pada had Jumat, sebahagian pakkaja (nelayan) tidak pergi ke laut, kalau pergi, ia tidak jauh dan iaharus memperhitungkan waktu Jumat. Begitupula pakkaja yang biasa tinggalkan kampung sampai satu minggu atau lebih, pada hari Jumat mereka sudah berada di kampungnya, kalau tidak dapat sampai, maka ia mencari mesjid yang dekat ditempat dimana ia mencari ikan. Shalat Jumat selain bernilai agama, ia juga mengandung aspek sosial, karena pada waktu itu anggota masyarakat dapat saling tukar informasi masalah "keduniaannya",pada waktu itu juga dapat diketahui seseorang tidak ada dikampung atau ia sakit.

Zakat fitrah yang merupakan kewajiban setiap muslim, tetap dikeluarkan, sekalipun kurang mampu. Orang tua yang ada anaknya di luar pulau Kambuno, tetap juga merasa bertanggung jawab untuk mengeluarkan zakatnya, kecuali ada penyampaian sebelumnya atau mereka sudah kawin. Zakat fitrah selain diterima oleh amal zakat yang telah ditetapkan, dukun, guru mengaji tetap juga menerima. Biasanya anak-anak mengaji mengeluarkan zakatnya kepada gurunya, dan anak sekitar lima tahun ke bawah mengeluarkan zakatnya kepada dukun. Menurut informasi dari Imam Kelurahan, bahwa sampai sekarang belum pemah menerima zakat harta.

Pada bulan puasa, orang Kambuno merasa malu kalau ada dapurnya berasap, karena bisa dianggap penghuninya tidak berpuasa. Pada siang hari tidak kelihatan orang mengisap rokok, pemuda-pemuda atau sawi yang tidak berpuasa, ia secara sembunyi-sembunyi mengisap rokok. Dahulu pada malam hari ramadhan ramai sekali mesjid, namun perkembangan sekarang ini tidaklah demikian, karena adanya paham dari kelompok pesantren yang dipimpin sekarang Imam Kampung bahwa shalat tarawih itu bukan sunnah dan tidak pernah dilakukan Nabi, tetapi yang ada hanya shalat $M l$, sehingga pada jam dua malam melalui pengeras suara mengajak orang datang ke mesjid. Tetapi tradisi melaksanakan tarawih belum dapat dirubah, dan menurut Pak Imam, untuk merubah tradisi seperti ini harus bertahap.

Seorang yang telah menunaikan haji di Mekah, dianggap mabbarakka pallolonganna (pendapatannya mendapat berkah). Tahun ini (1989) ada sebanyak 12 orang naik Mekah, dan 7 diantaranya itu adalah orang dari Pulau Kambuno. Diantara ke tujuh orang itu selain pegawai adalah ponggawa dan keluarganya. Nampakanya sawi dan nelayan biasa sulit mengumpulkan uang untuk menunaikan haji. Bahkan sawi daripassellu (penyelam teripang), sepanjang tahun dijerat dengan utang, karena sebelum berangkat ia sudah mengambil uang dari ponggawanya, setelah kembali dipotong, kemudian mengambil lagi, sehingga sering didengar ungkapan bahwa mereka memberi makan utang kepada keluarganya, bahkan terkadang mewariskan utang kepada anakanaknya.

Sejak masuknya golongan pesantren, beberapa praktek keagamaan yang telah dirubah yang menyebabkan terjadinya konflik antara Muhammadiyah dan"Ahlusunnah" satu pihak dan golongan pesantren di pihak lain. Pada tahun 1983, ditiadakan takbir 7 kali sholat hari raya, dan pada tahun 1986 ditiadakan pengajian Al-Quran menjelang masuk waktu shalat karena dianggap bid'ah. Dan terakhir ini sampai sekarang masih menjadi pembicaraan orang, sehingga ada orang menjadikan alasan

No. 1 \& 2 Thn. I Juli / Desember 1990 
tidak shalat jamaah karena waktu terlalu singkat untuk mempersiapkan diri ke mesjid. Selain itu, sesudah shalat tidak dibacakan lagi lailaha illallah, subhanallah, alhamdullillah dan allahu akbar secara berjamaah dan imam tidak mengangkat tangan ketika berdoa, tidak ada lagi bersalam-salaman sesudah shalat. Dalam pesta perkawinan, tidak boleh pengantin duduk bersanding, bahkan tamu laki-laki tidak boleh melihat pengantin perempuan, begitu pula sebaliknya, dan acaranya cenderung tidak ramai, karena tidak boleh ada hiburan semacam orkes. Namun biaya perkawinan yang diterima oleh pihak wanita tidak berbeda dengan warga masyarakat lain, yaitu antara $\mathrm{Rp}$. 500.000,- - Rp. 2.000.000,-

Hubungan antara pemcrintah dalam hal ini Kepala Kelurahan dengan tokoh-tokoh agama tidak selalu harmonis. Satu pihak menilai pemerintah "lemah" memimpin, dan tidak aktif menjelangkan shalat lima waktu secara berjamaah di mesjid, di pihak lain pemerintah beranggapan pelanggaran yang harus diberikan seseorang tidak boleh melampaui ketentuan (seperti orang yang berzina harus disiksa kemudian diarak keliling kampung, hal ini tidak dilakukan oleh Pak Lurah), dan ketidak aktifan Pak Lurah shalat jemaah menurut alasannya karena praktek ibadah tidak sesuai dengan pemahamannya. Pergantian Imam Kampung yang sekarang mewarnai corak pelaksanaan ibadah di mesjid dapat saja dilakukan oleh Pak Lurah, tetapi selain sulitnya didapat pengganti, orang yang ada dibelakang Imam Kampung harus diperhitungkan, karena mereka adalah tokoh masyarakat dan sebahagian ponggawa yang sangat berpengaruh, dan mempunyai andil sangat besar terhadap pembangunan sarana keagamaan di Kambuno. 


\section{BUKU KEPUSTAKAAN}

\section{Abu Hamid, Pertumbuhan Pemukiman 1986 Masyarakat di Lingkungan Perairan Dearah Sulawesi Se- latan, Jakarta : Dep. P dan K

$\begin{aligned}- & -\end{aligned}$

1988

, Pola Pengembangan Masyarakat Nelayan di Sulawesi Selatan. (Studi Sosio Antropologi Ekonomi), Ujung Pandang : Bappeda Propinsi Daerah Tkt I Sulawsi Selatan dan Umbas

Abdullah, Taufik, (ed) Agama, Etos Kerja

1979 dan Perkembangan Ekonomi, Jakarta : LP3ES

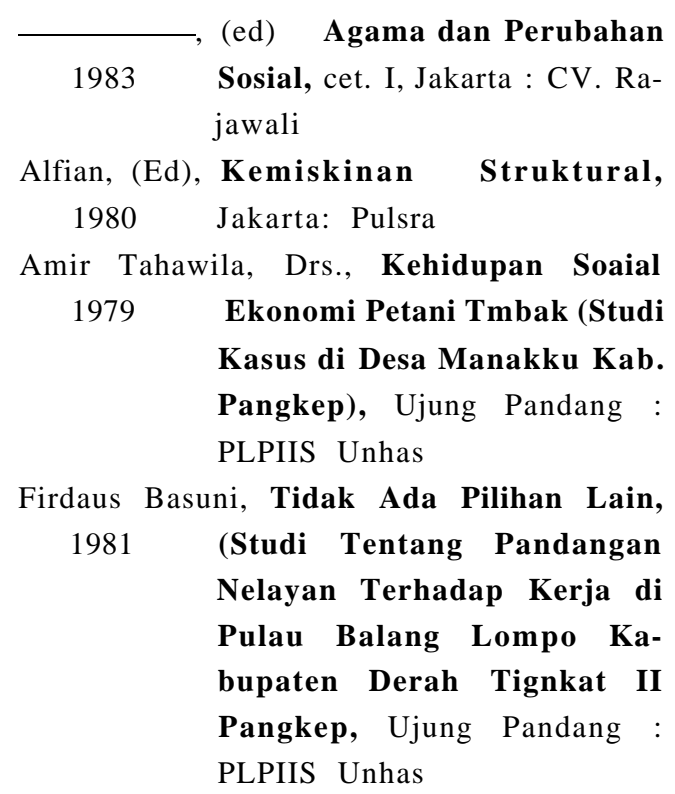

No. 1 \& 2 Thn. I Juli / Desember 1990
Geertz, Clifford, Abangan, Santri, Proyayi, 1980 Da lam Masyarakat Jawa, Cet. II Jakarta: Pustaka Jaya

Hasanuddin, Basri, Beberapa Hal Mengenai 1982 Pemasaran Hasil Pantai, Ujung Pandang : Majalah Lontara No. 8 tahun XXI 1982

Ihromi, T.O., (ed), Pokok-Pokok Antropo1980 logi Budaya, Jakarta : PT. Gramedia

Koentjaraningrat, (ed) Beberapa Pokok An1981 tropologi Sosial, cet. V, Jakarta: Dian Raya

(ed) Manusia dan Kebudayaan 1987 di Indonesia, cet. XI, Jakarta : Djambatan

Mattulada, LATOA, Suatu Lukisan Analisis 1975 Terhadap Antropologi Politik Orang Bugis, Disertasi Doktor, Jakarta : Universitas Indonesia.

Mukhlis (ed), Dinamika Bugis Makassar, 1986 PT. SInar Kridda untuk PLPIIS dan YIIS

\begin{tabular}{cc}
\hline \multirow{2}{*}{1988} & Dimensi SOsial Kawasan Pan- \\
& tai, Jakarta : S.A. Brother's \\
& untuk The Toyota Foundation \\
, Persepsi Sejarah Kawasan & Pantai, Jakarta : S.A. Brother's \\
& untuk The Toyota Foundation \\
& Persepsi Sejarah Kawasan Pan- \\
& tai, Jakarta : S.A. Brother's untuk \\
& The Toyota Foundation \\
Mubyarto (dkk), Nelayan dan Kemiskinan, & AGro Ekonomika, Jakarta: CV. \\
$1982 \quad$ Rajawali \\
Rahim, Husain, Pewarisan Nilai-Nilai \\
$1985 \quad$ Agama pada Masyarakat \\
Bugis, dalam Agama dan Reli-
\end{tabular}


tas Sosial, Mukhlis dan Kathryn Robinson (ed), Ujung Pandang : Lembaga Penerbitan Unhas Resusun, Demianus, Dayung Basah Periuk 1978 Berisi, (Studi tentang Beberapa Aspek Sosial Ekonomi Nelayan Bagang di Pulau Sembilan Kecamatan Sinjai Utara), Hasil Penelitian, Ujung Pandang : PLPIIS Unhas

Pohan, Rusdin, Pola Kebutuhan Pokok 1982 Keluarga Nelayan Pulau (Studi Kasus Pulau Sembilan, Sinjai Utara) Ujung Pandang : PLPIIS Unhas
Saifuddin, Achmad Fedyani, Drs. M.A., 1986 Konflik dan Integrasi (Perbedaan faham dalam Agama Islam), Jakarta : CV. Rajawali

Sallatang, Arifin, Desa Pantai di Sulawesi 1976 Selatan dan Strategi Pembangunannya, Ujung Pandang : Team Studi Pedesaan Universitas Hasanuddin

Tahir, A.R., (dkk) Studi Tentang Sistem 1978 SOsial Masyarakat Bajo di Sulawsi Selatan dan Tenggara, Laporan Penelitian, Ujung Pandang : Proyek Penelitian Universitas Hasanuddin

Wiajaya, A.N., Manusia Indonesia, Individu, 1986 Keluarga dan Masyarakat, Jakarta : Akemi 